\title{
PENGARUH JUMLAH WAJIB PAJAK TERDAFTAR DAN PENERBITAN SURAT PAKSA TERHADAP PENERIMAAN PAJAK PENGHASILAN PADA KPP PRATAMA BANTUL
}

\author{
Nanik fitriani \\ Program Studi Akuntansi Fakultas Ekonomi \\ Universitas Sarjanawiyata Tamansiswa \\ nanikfitriani28@yahoo.com
}

\begin{abstract}
This study aims to determine the effect of total and publishing Registered Taxpayers Forced letter of acceptance in the KPP Pratama Bantul Income Tax. Analysis used is multiple regression analysis. Before using multiple regression analysis, performed classical assumption test. Partial hypothesis test results (t-test) showed a variable amount of Registered Taxpayers positive and significant effect issue of forced variable has no effect on income tax receipts. Simultaneous hypothesis test results (F-test) shows the number of Registered Taxpayers and variable force simultaneous issuance of a significant positive effect on income tax receipts. This study showed 35,1 \% income tax receipts are affected by variable amounts Registered Taxpayers and issue of Forced and 64,9\% explained by other factors outside the discussion.
\end{abstract}

Keyword: the number of registered taxpayers, issue of forced labor, withholding tax

\section{PENDAHULUAN}

Sumber penerimaan negara Indonesia berasal dari rakyat melalui pungutan pajak dan/atau dari hasil kekayaan alam yang ada di dalam negara Indonesia. Penghasilan tersebut digunakan untuk membiayai kepentingan umum yang juga mencakup kepentingan pribadi individu seperti kesehatan rakyat, pendidikan, kesejahteraan, dan sebagainya. Salah satu penerimaan pajak potensial adalah pajak penghasilan. Dalam empat tahun terakhir sejak tahun 2008, penerimaan pajak mengalami peningkatan, termasuk pajak penghasilan. Data yang menunjukkan penerimaan negara, penerimaan pajak dan penerimaan pajak penghasilan $(\mathrm{PPh})$ dalam kurun waktu 2008 -2011 adalah sebagai berikut:

Tabel 1

Penerimaan Negara, Penerimaan Pajak dan Penerimaan Pajak Penghasilan

Tahun 2008 - 2011

(Dalam Milyar Rupiah)

\begin{tabular}{cccc}
\hline Tahun & $\begin{array}{c}\text { Penerimaan } \\
\text { Negara }\end{array}$ & $\begin{array}{c}\text { Total } \\
\text { Penerimaan } \\
\text { Pajak }\end{array}$ & $\begin{array}{c}\text { Penerimaan } \\
\text { PPh }\end{array}$ \\
\hline $\mathbf{2 0 0 8}$ & 979,305 & 658,701 & 327,498 \\
$\mathbf{2 0 0 9}$ & 847,096 & 619,922 & 317,615 \\
$\mathbf{2 0 1 0}$ & 992,249 & 723,307 & 357,045 \\
$\mathbf{2 0 1 1}$ & $1,205,346$ & 873,874 & 431,122 \\
\hline
\end{tabular}

Sumber: BPS, 2013, data diolah. 
Data tersebut menunjukkan bahwa dalam kurun waktu 4 (empat) tahun mulai tahun 2008 sampai tahun 2011 pajak memiliki peran penting dalam menyumbang penerimaan Negara (lebih dari separuh). Data tersebut juga menunjukkan bahwa Pajak Penghasilan mendominasi total penerimaan pajak, yaitu lebih dari separuh total penerimaan pajak. Meningkatnya penerimaan pajak penghasilan merupakan akibat dari pertumbuhan ekonomi masyarakat yang disertai kesadaran dari masyarakat sebagai Wajib Pajak dalam memenuhi kewajiban perpajakannya (www.ekon.go.id). Kepatuhan Wajib Pajak yang semakin baik tidak terlepas dari sistem perpajakan yang saat ini diberlakukan, yaitu self assessment system dimana Wajib Pajak diberi kepercayaan penuh untuk menghitung, membayar dan melaporkan sendiri pajak yang terutang.

Dalam rangka mensukseskan pelaksanaan self assessment system dibutuhkan beberapa prasyarat dari Wajib Pajak, antara lain kesadaran, kejujuran, kemauan membayar pajak, dan kedisiplinan Wajib Pajak. Kesadaran Wajib Pajak meliputi kesadaran kewajiban mendaftarkan diri untuk dicatat sebagai Wajib Pajak dan untuk mendapatkan Nomor Pokok Wajib Pajak (NPWP) pada kantor Direktorat Jenderal Pajak. Pendaftaran NPWP dapat dilakukan pada Kantor Pelayanan Pajak (KPP) atau Kantor Pelayanan Penyuluhan dan Konsultasi Perpajakan (KP2KP) yang wilayah kerjanya meliputi tempat tinggal atau tempat kedudukan Wajib Pajak. Fasilitas yang disediakan Direktorat Jenderal Pajak adalah layanan e-registration yang dapat diakses melalui http://www.pajak.go.id.

Pada tahun 2008 Direktorat Jenderal Pajak juga memberikan fasilitas berupa Sunset Policy. Upaya ini mendapat respon positif dari masyarakat, terbukti dengan adanya 12 (dua belas) juta lebih masyarakat yang mendaftarkan diri untuk memperoleh NPWP (http://log.viva.co.id).

Adanya berbagai fasilitas dan kemudahan tersebut diharapkan akan lebih banyak Wajib Pajak yang mendaftarkan diri untuk memperoleh NPWP sehingga target penerimaan pajak terutama Pajak Penghasilan dapat tercapai. Semakin tinggi kesadaran masyarakat untuk mendapatkan NPWP diharapkan dapat menambah penerimaan negara dari sektor pajak terutama pajak penghasilan. Hal ini sesuai dengan penelitian Liswatin (2005) dalam Dewi (2007), dari hasil perhitungan terdapat pengaruh Wajib Pajak terdaftar terhadap penerimaan Pajak Penghasilan adalah positif. Keadaan ini menjelaskan jika terjadi kenaikan variabel sebesar satu Wajib Pajak terdaftar, maka penerimaan Pajak Penghasilan akan mengalami kenaikan sebesar 0,364 milyar atau Rp 364.000.000 dengan asumsi variabel lainnya konstan. Gunawan (2012) menyatakan bahwa pengaruh jumlah kepemilikan NPWP terhadap penerimaan pajak menunjukkan nilai signifikansi 0,246 yang berarti nilai ini lebih besar dari 0,05 sedangkan t-hitung sebesar 1,182. Hal ini berarti kepemilikan NPWP tidak berpengaruh signifikan terhadap pajak penghasilan.

Semakin banyak Wajib Pajak terdaftar maka tanggung jawab Direktorat Jenderal Pajak juga semakin besar. Direktorat Jenderal Pajak berkewajiban untuk melakukan pelayanan, pengawasan, pembinaan/ penyuluhan, dan penerapan sanksi pajak. Pengawasan dan pembinaan yang dilakukan oleh Direktorat Jenderal Pajak bertujuan untuk meminimalisir kelalaian Wajib Pajak dalam melaksanakan kewajibannya. Kelalaian Wajib Pajak secara sengaja maupun tidak sengaja dapat menimbulkan kerugian negara. Sebagai upaya pengawasan terhadap Wajib Pajak, Direktorat Jenderal Pajak berhak melakukan penagihan pajak atas hutang pajak yang ditanggung Wajib Pajak. Direktorat Jenderal Pajak dapat melakukan tindakan penagihan pajak apabila jumlah pajak yang terutang berdasarkan Surat Tagihan Pajak (STP), Surat Ketetapan Pajak Kurang Bayar (SKPKB), Surat Ketetapan Pajak Kurang Bayar Tambahan (SKPKBT), Surat Keputusan Pembetulan, Surat Keputusan 
Keberatan, Putusan Banding, serta putusan Peninjauan Kembali yang menyebabkan jumlah pajak yang masih harus dibayar bertambah, yang tidak dibayar oleh Penanggung Pajak sesuai dengan jangka waktu yang ditetapkan dalam peraturan perundang-undangan perpajakan.

Penerbitan Surat Paksa diharapkan dapat menambah penerimaan pajak terutama pajak penghasilan, sesuai dengan pernyataan Syahab dan Gisijanto (2008) yang menyatakan bahwa penagihan pajak dan surat paksa mempunyai pengaruh yang signifikan terhadap penerimaan pajak. Variabel ini memberikan kontribusi pengaruh langsung dan tidak langsung terhadap penerimaan $\mathrm{PPh}$ Badan yaitu penagihan pajak sebesar $15,01 \%$, dan surat paksa pajak sebesar 8,78\%. Marduati (2012) dalam penelitiannya menyimpulkan bahwa jumlah surat paksa yang diterbitkan berpengaruh secara positif dan signifikan terhadap pencairan tunggakan pajak. Hal ini terbukti pada nilai t hitung (2.345) lebih besar dari nilai t tabel (2.035) dengan nilai signifikansi (0.025) lebih kecil dari batas signifikansi (0.05). Pada variabel surat paksa diperoleh nilai koefisien regresi (b2) sebesar 11840.459 atau bertanda positif maka dapat dikatakan bahwa jika jumlah surat paksa yang diterbitkan mengalami peningkatan maka pencairan tunggakan pajak di KPP Pratama Makassar Barat akan meningkat. Hal ini berarti dengan bertambahnya pencairan tunggakan pajak di KPP Pratama Makassar Barat maka penerimaan pajak juga meningkat. Sedangkan penelitian Nugraha (2012) menyatakan bahwa penerbitan surat paksa tidak berpengaruh signifikan terhadap penerimaan pajak.

Dari uraian diatas, dapat ditarik kesimpulan sementara bahwa jumlah Wajib Pajak yang terdaftar dan penerbitan Surat Paksa tidak selalu menambah penerimaan pajak, terutama pajak penghasilan. Padahal, jumlah Wajib Pajak yang terdaftar cukup menjanjikan bagi tercapainya penerimaan Pajak Penghasilan yang lebih maksimal. Penerbitan Surat Paksa juga cukup menjanjikan bagi tercapainya penerimaan
Pajak Penghasilan yang lebih maksimal sebab Surat Paksa mempunyai aturan yang sangat tegas yaitu utang pajak harus dilunasi dalam jangka waktu 2 x 24 jam setelah Surat Paksa diberitahukan oleh Jurusita Pajak.

\section{LANDASAN TEORI \\ Definisi Pajak dan Pajak Penghasilan}

Menurut Undang-undang Ketentuan Umum dan Tata Cara Perpajakan Pasal 1 ayat (1), pajak adalah kontribusi wajib kepada negara yang terutang oleh orang pribadi atau badan yang bersifat memaksa berdasarkan Undang-Undang dengan tidak mendapatkan imbalan secara langsung dan digunakan untuk keperluan negara bagi sebesar-besarnya kemakmuran rakyat. Pajak Penghasilan adalah pajak yang dikenakan atas penghasilan yang diterima.

\section{Objek Pajak Penghasilan}

Objek pajak yaitu sesuatu yang dikenakan pajak atau dapat diartikan sebagai sasaran pengenaan pajak. Objek pajak penghasilan adalah penghasilan. Pengertian penghasilan menurut Undang-undang Pajak Penghasilan adalah setiap tambahan kemampuan ekonomis yang diterima atau diperoleh Wajib Pajak, baik yang berasal dari Indonesia maupun dari luar Indonesia, yang dapat dipakai untuk konsumsi atau untuk menambah kekayaan Wajib Pajak yang bersangkutan, dengan nama dan dalam bentuk apapun.

\section{Subjek Pajak Penghasilan}

Subjek pajak yaitu pihak pihak (orang maupun badan) yang akan dikenakan pajak. Subjek Pajak Penghasilan adalah orang pribadi, warisan yang belum terbagi sebagai satu kesatuan menggantikan yang berhak, badan dan Bentuk Usaha Tetap (BUT).

\section{Nomor Pokok Wajib Pajak (NPWP)}

Dalam Undang-Undang Nomor 6 Tahun 1983 tentang Ketentuan Umum Dan Tata Cara Perpajakan STDD UndangUndang Nomor 16 Tahun 2009 pasal 1, yang dimaksud dengan Nomor Pokok Wajib Pajak adalah nomor yang diberikan kepada Wajib 
Pajak sebagai sarana dalam administrasi perpajakan yang dipergunakan sebagai tanda pengenal diri atau identitas Wajib Pajak dalam melaksanakan hak dan kewajiban perpajakannya.

Wajib Pajak (WP) adalah orang pribadi atau badan meliputi pembayar pajak, pemotong pajak, dan pemungut pajak, yang mempunyai hak dan kewajiban perpajakan sesuai dengan ketentuan peraturan perundang-undangan perpajakan. Wajib Pajak. Wajib Pajak terdaftar dalam penelitian ini adalah:

a) Wajib Pajak baik Orang Pribadi maupun

Badan yang telah terdaftar pada Kantor

Pelayanan Pajak Pratama Bantul.

b) Wajib Pajak telah diberikan Nomor

Pokok Wajib Pajak.

NPWP berfungsi sebagai tanda pengenal diri atau identitas Wajib Pajak serta untuk menjaga ketertiban dalam pembayaran pajak dan dalam pengawasan administrasi perpajakan.

\section{Penagihan Pajak dengan Surat Paksa (PPSP)}

Penagihan pajak dapat dikelompokkan menjadi 2 (dua) yaitu penagihan aktif dan penagihan pasif. Penagihan pajak pasif dilakukan dengan menggunakan Surat Tagihan Pajak (STP), Surat Ketetapan Pajak Kurang Bayar (SKPKB), Surat Ketetapan Pajak Kurang Bayar Tambahan (SKPKBT), Surat Keputusan Pembetulan yang menyebabkan pajak terutang menjadi lebih besar, Surat Keputusan Keberatan yang menyebabkan pajak terutang menjadi lebih besar, Surat Keputusan Banding yang menyebabkan pajak terutang menjadi lebih besar. Jika dalam jangka waktu 30 (tiga puluh) hari tidak dilunasi, maka 7 (tujuh) hari setelah jatuh tempo akan diikuti dengan penagihan pajak secara aktif yang dimulai dengan menerbitkan surat teguran.

Berdasarkan Undang-Undang Republik Indonesia Nomor 19 Tahun 2000 tentang Perubahan Atas Undang-Undang Nomor 19 Tahun 1997 Tentang Penagihan Pajak Dengan Surat Paksa, dijelaskan bahwa:

a) Surat Paksa diterbitkan apabila:

1) Penanggung Pajak tidak melunasi utang pajak dan kepadanya telah diterbitkan Surat Teguran atau Surat Peringatan atau surat lain yang sejenis;

2) Terhadap Penanggung Pajak telah dilaksanakan penagihan seketika dan sekaligus; atau

3) Penanggung Pajak tidak memenuhi ketentuan sebagaimana tercantum dalam keputusan persetujuan angsuran atau penundaan pembayaran pajak.

b) Surat Teguran, Surat Peringatan atau surat lain yang sejenis diterbitkan apabila Penanggung Pajak tidak melunasi utang pajaknya sampai dengan tanggal jatuh tempo pembayaran.

\section{Kerangka Pikir}

Sekaran dalam Sugiyono (2010:88) mengemukakan bahwa kerangka berfikir merupakan model konseptual tentang bagaimana teori berhubungan dengan berbagai faktor yang telah diidentifikasi sebagai masalah yang penting.

Adapun kerangka pemikiran yang digunakan dalam penelitian ini adalah sebagai berikut:

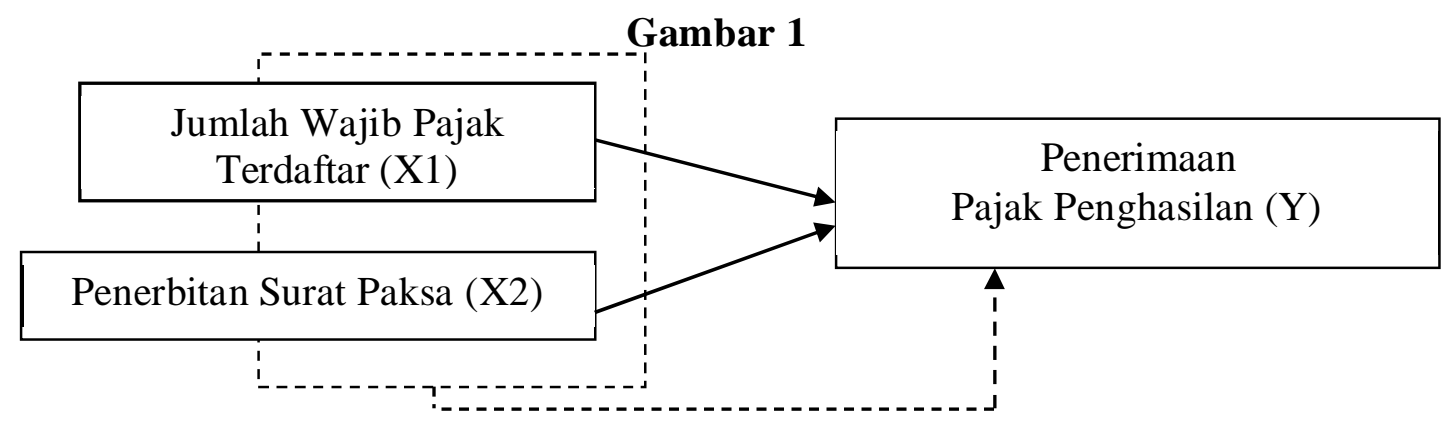




\section{METODOLOGI PENELITIAN}

Penelitian ini bersifat penelitian deskriptif kuantitatif. Penelitian deskriptif adalah penelitian yang menggambarkan suatu fenomena dengan mendeskripsikan variabel yang berkenaan dengan masalah yang diteliti. Data yang digunakan dalam penelitian ini merupakan data sekunder yang diperoleh secara langsung dari Kantor Pelayanan Pajak Pratama Bantul. Sampel data yang digunakan adalah laporan realisasi jumlah Wajib Pajak terdaftar dan penerbitan surat paksa oleh Kantor Pelayanan Pajak Pratama Bantul setiap bulan mulai tahun 2008 sampai dengan tahun 2011.

Metode pengumpulan data diperoleh dengan dokumentasi. Arikunto dalam bukunya Prosedur Penelitian Suatu Pendekatan Praktik (2010) menyatakan bahwa metode dokumentasi adalah mencari data mengenai hal-hal atau variabel yang berupa catatan, transkrip, buku, surat kabar, majalah, prasasti, notulen rapat, lengger, agenda dan sebagainya. Penelitian ini menggunakan data berupa laporan realisasi penerimaan pajak, jumlah Wajib Pajak terdaftar dan jumlah Surat Paksa yang diterbitkan.

\section{ANALISI DAN PEMBAHASAN}

Jumlah sampel pada penelitian ini adalah 48 bulan dengan jumlah sampel valid sebanyak 43 bulan. Hal ini disebabkan karena terdapat 5 bulan dimana KPP Pratama Bantul tidak menerbitkan surat paksa, sehingga data dalam SPSS tereliminasi. Hasil uji asumsi klasik adalah data berdistribusi normal, tidak terjadi problem heteroskedastisitas, tidak terjadi problem autokorelasi, dan tidak terjadi problem multikolinieritas. Selanjutnya untuk menguji hipotesis yang telah dibuat sebelumnya, peneliti melakukan analisis regresi linier, uji signifikansi parameter individual (uji t) dan uji signifikansi simultan (uji F).

Tabel 2

Output Analisis Regresi Berganda

\begin{tabular}{|c|c|c|c|c|c|}
\hline \multicolumn{6}{|c|}{ Coefficients $^{\mathrm{a}}$} \\
\hline Model & Unstandardizec & Coefficients & $\begin{array}{l}\text { Standardized } \\
\text { Coefficients }\end{array}$ & $\mathrm{t}$ & Sig. \\
\hline & B & Std. Error & Beta & & \\
\hline $\begin{array}{l}\text { (Constan } \\
\text { t) }\end{array}$ & $\begin{array}{r}2031344862 . \\
881\end{array}$ & $\begin{array}{r}1453960054 . \\
434\end{array}$ & & 1.397 & .170 \\
\hline $\mathrm{X} 1$ & 129740.950 & 26179.231 & .675 & 4.956 & .000 \\
\hline $\mathrm{X} 2$ & $\begin{array}{r}25317797.02 \\
7 \\
\end{array}$ & $\begin{array}{r}10657799.10 \\
3\end{array}$ & -.324 & -2.376 & .022 \\
\hline
\end{tabular}

a. Dependent Variable: Y

Berdasarkan tabel 2 diketahui bahwa terdapat pengaruh signifikan $(0,000<0,05)$ positif antara jumlah Wajib Pajak Terdaftar dengan penerimaan Pajak Penghasilan. Hal ini disebabkan oleh banyaknya Wajib Pajak efektif baik orang pribadi maupun badan yang mendaftarkan diri untuk mendapatkan NPWP serta melaksanakan kewajiban perpajakannya. Kewajiban perpajakan berupa kewajiban menghitung, membayar dan melaporkan Pajak Penghasilan yang terutang. Semakin banyak jumlah Wajib Pajak terdaftar pada KPP Pratama Bantul maka akan semakin menambah penerimaan Pajak Penghasilan. Banyaknya bisnis UMKM di Bantul juga ikut berperan dalam menambah penerimaan Pajak Penghasilan. Hasil penelitian ini mendukung hasil 
penelitian Hidayat (2008) yang menyatakan bahwa kegiatan ekstensifikasi (pemberian NPWP) memberikan pengaruh signifikan terhadap penerimaan Pajak Penghasilan yang dibuktikan dengan t-hitung > t-tabel $(3,75>$ 2,132) dengan Koefisien Determinasi sebesar $77,5 \%$ pada tingkat kepercayaan $95 \%(\alpha=$ $0,05)$.

Suhendra (2010) menyatakan bahwa penerimaan pajak penghasilan badan disebabkan oleh pengetahuan wajib pajak yang meningkat. Kondisi seperti itu akan berdampak positif pada perilaku Wajib Pajak terhadap kesadaran dan kepatuhan dalam menghitung dan membayar sendiri utang pajak yang terutang, serta menyampaikan SPT (Surat Pemberitahuan) tepat pada waktunya sehingga akan signifikan positif terhadap penerimaan pajak penghasilan badan setiap tahunnya.

Variabel penerbitan surat paksa berdasarkan tabel 2 diketahui bahwa tidak terdapat pengaruh antara penerbitan surat paksa dengan penerimaan Pajak Penghasilan. Dalam penelitian ini, nilai $t$ hitung adalah 2,376 ( $<\mathrm{t}$ tabel 2,018) sehingga korelasinya berbanding terbalik dengan penerimaan pajak penghasilan. Bila surat paksa yang diterbitkan bertambah maka penerimaan pajak penghasilan akan menurun dan sebaliknya, jika surat paksa yang diterbitkan berkurang maka penerimaan pajak penghasilan akan bertambah. Hal ini dapat disebabkan karena saat diterbitkan surat paksa Wajib Pajak tidak diketahui keberadaannya. Sebab lainnya adalah usaha sudah tidak lagi beroperasi/ dilikuidasi atau Wajib Pajak tidak memiliki aset untuk disita sehingga pajak yang terutang tidak dapat ditagih oleh Juru Sita. Hasil penelitian ini mendukung penelitian Nugraha (2012) yang menyatakan bahwa penerbitan surat paksa tidak berpengaruh signifikan terhadap penerimaan pajak.

Tabel 3

Output Uji F

ANOVA

\begin{tabular}{lrcrrr} 
Model & Sum of Squares & Df & Mean Square & F & Sig. \\
\hline Regressio & 194288099142866470 & & 97144049571433230 & 12.35 & \\
$\mathrm{n}$ & 000.000 & 2 & 000.000 & 4 & $.000^{\mathrm{b}}$ \\
Residual & 314533182621241900 & \multirow{2}{*}{40} & 78633295655310479 & & \\
& 000.000 & & 00.000 & & \\
Total & 508821281764108400 & \multirow{2}{*}{42} & & & \\
& 000.000 & & & & \\
\hline
\end{tabular}

a. Dependent Variable: Y

b. Predictors: (Constant), X2, X1

Hasil uji F menunjukkan F-hitung $>$ Ftabel $(12,354>3,232)$, menunjukkan bahwa variabel jumlah Wajib Pajak Terdaftar dan penerbitan surat paksa secara simultan berpengaruh signifikan terhadap penerimaan pajak penghasilan. Semakin banyak jumlah Wajib Pajak Terdaftar yang melaksanakan kewajiban perpajakannya dan penerbitan Surat Paksa sebagai penagihan atas utang pajak terhadap Wajib Pajak memberikan dampak yang positif terhadap penerimaan Pajak Penghasilan pada KPP Pratama Bantul. Variabel jumlah Wajib Pajak Terdaftar mempunyai pengaruh yang sangat kuat terhadap penerimaan Pajak Penghasilan. Agung (2012) menyatakan bahwa secara simultan terdapat pengaruh jumlah Wajib Pajak, jumlah pemeriksaan pajak dan jumlah surat paksa terhadap penerimaan pajak dengan nilai signifikansi $0,001<0,005$. 
Tabel 4

Output Koefisien Determinasi

Model Summary ${ }^{b}$

\begin{tabular}{lrrrr}
$\begin{array}{l}\text { Mode } \\
1\end{array}$ & R & R Square & Adjusted R Square & $\begin{array}{c}\text { Std. Error of the } \\
\text { Estimate }\end{array}$ \\
\hline 1 & $.618^{\mathrm{a}}$ & .382 & .351 & 2804162899.25016 \\
\hline
\end{tabular}

a. Predictors: (Constant), X2, X1

b. Dependent Variable: Y

Hasil koefisien determinasi menunjukkan $35,1 \%$ penerimaan pajak penghasilan di KPP Pratama Bantul dijelaskan oleh variabel jumlah Wajib Pajak Terdaftar dan penerbitan surat paksa. Sedangkan sisanya $64,9 \%$ dijelaskan oleh variabel lain yang tidak diteliti dalam penelitian ini.

\section{SIMPULAN}

Hasil uji signifikansi parameter individual (uji t) menunjukkan bahwa jumlah Wajib Pajak Terdaftar mempunyai pengaruh signifikan positif terhadap penerimaan Pajak Penghasilan sedangkan penerbitan surat paksa tidak berpengaruh terhadap penerimaan Pajak Penghasilan. Hasil uji signifikansi simultan (uji F) menunjukkan bahwa variabel jumlah Wajib Pajak Terdaftar dan penerbitan surat paksa secara simultan berpengaruh signifikan terhadap penerimaan pajak penghasilan.

\section{DAFTAR PUSTAKA}

Arikunto, S, 2010, Prosedur Penelitian Suatu Pendekatan Praktik, Rineka Cipta Jakarta

Dewi, Ivana Puspa, 2007, Analisis Variabel Variabel Yang Mempengaruhi Tingkat Penerimaan PPh Orang Pribadi (Studi Kasus di Kantor Pelayanan Pajak Batu), Skripsi, Universitas Brawijaya

Gunawan, Rony, 2012, Pengaruh Jumlah Kepemilikan NPWP, Pelaporan SSP, dan Pemeriksaan Pajak Terhadap Penerimaan Pajak Penghasilan Wajib Pajak Badan Pada KPP Pratama
Karanganyar, Universitas Negeri Semarang

Hidayat, A.G.A, 2008, Pengaruh Kegiatan Ekstensifikasi Terhadap Penerimaan Pajak Penghasilan Orang Pribadi (Studi Kasus Pada Wajib Pajak Orang Pribadi Dalam Negeri di KPP Pratama Bandung-Tegallega), Universitas Widyatama

http://log.viva.co.id

Marduati, Andi, 2012, Pengaruh Penagihan Pajak Dengan Surat Teguran Dan Surat Paksa Terhadap Pencairan Tunggakan Pajak Di Kantor Pelayanan Pajak Pratama Makassar Pengaruh Jumlah Wajib Pajak, Pemeriksaan Pajak dan Penagihan Pajak dengan Surat Paksa Terhadap Penerimaan Pajak di Kantor Pelayanan Pajak Pratama Medan Petisah, Perpustakaan Unimed

Sugiyono, 2010, Metode Penelitian Bisnis (Pendekatan Kuantitatif, Kualitatif, dan $R \& D)$, Alfabeta Bandung

Suhendra, Euphrasia Susy, 2010, Pengaruh Tingkat Kepatuhan Wajib Pajak Badan Terhadap Peningkatan Penerimaan Pajak Penghasilan Badan, Jurnal Ekonomi Bisnis Vol.15 No.1, Edisi April,

Syahab, Zakiah M dan Gisijanto, Hantoro Arief, 2008, Pengaruh Penagihan Pajak, dan Surat Paksa Terhadap Penerimaan Pajak Penghasilan Badan, 
Jurnal Ekonomi Bisnis No.2 Vol. 13, www.ekon.go.id Edisi Agustus 